\title{
Allometric Variation on Cuspal Areas of the Lower First Molar in Three Racial Populations
}

\author{
Eisaku Kanazawa, Mitsuo SekIKAWA, Junji AKAI \\ and Tadashi OZAKI \\ Department of Anatomy, Nihon University School \\ of Dentistry at Matsudo
}

\begin{abstract}
Cusp areas of the mandibular first molar were measured in five groups of three racial populations: Japanese male and female, Dutch, and Australian Aboriginals male and female. Total values of five cusp areas were the largest in Aboriginals, $114.9 \mathrm{~mm}^{2}$, and the smallest in Dutch, 96.1 $\mathrm{mm}^{2}$. Percent cusp areas (\% of total area) do not show population differences. However, there was a tendency that the proportion of these five areas in Aboriginals approximates to those of fossil hominids having large teeth. Correlations between percent cusp areas and the total value show deviations from isometry to allometry. Then, correlation coefficients, regression slope and standard error of slope were obtained from log cusp areas and log total area in order to obtain allometric coefficients. Results of the test for isometry of regression slope show that hypoconid except for Dutch, and protoconid and metaconid except for Dutch and Japanese female have significant positive and negative allometry, respectively. The reason why Japanese female and Dutch do not show allometric trend may due to small size of the tooth and low frequency of 6th cusp. If the statistical allometric trend in the present study is reasonable analogues for allometric relationship within the fossil hominid taxa, the hypothetical reduction of the trigonid in the 'robust' Australopithecus may be an allometric phenomenon.
\end{abstract}

Keywords Cusp area, Allometry, Lower molar, Racial difference

\section{Introduction}

We have been engaged in three-dimensional measurement of the occlusal surface of human molars in several racial populations with the aid of the moiré method. It was found that the height and the position of the cuspal tips are different among popu- lations (KANAZAWA et al. 1983, SEKIKAWA et al. 1983, OzAKI et al. 1984, KANAZAWA et al. 1984, OzAKI et al. 1985). Cusp area is one of the other important quantitative features of occlusal surface. Relative size of cusp areas may have certain relations with groove patterns and/or the relative position of the cuspal tips. Although the 
racial differences of the groove pattern have been extensively investigated, those of the cusp areas have not been fully described yet. The purpose of this study is the demonstration of the racial difference of the absolute and relative cusp areas and of their allometric variation in three ethnic groups.

\section{Materials and Methods}

Materials were lower first molars of the following three populations.

(1) Japanese (Mongoloid): Plaster casts of the molars of 39 boys and 38 girls in a primary school in Ito city in Japan. Their ages were around 7 .

(2) Dutch (Caucasoid): Plaster casts were made from the molars preserved in the BoLK's collection of the University of Amsterdam. The sex had not been recorded on these 43 teeth in which hardly any attrition was found. Details of these teeth were reported elsewhere (OzAKI et al. 1984).

(3) Australian Aborigines (Australoid):
Plaster casts were copied from those of molars of Wailbri tribe preserved in the University of Adelaide. They are 24 males and 16 females. (The name of this population is shortly expressed as Aboriginals for convinience in this paper)

Plaster casts of the lower first molars were put in the standard position where three cuspal tips (protoconid, metaconid and entoconid) were on a horizontal plane which was perpendicular to the axis of the lens of a camera. We applied the moiré photography to measure cusp areas. Details of this method has already been described elsewhere (OzAKI and KanAZAWA, 1984). Moiré photographs not only provide immense three-dimensional informations of the surface, but also give clear indications of the boundaries between cusps by reading the contour lines.

Moiré photographs (Fig. 1) were enlarged to 8 times. Margins of five or six cusps were traced on a digitizer (Talos, $0.02 \mathrm{~mm}$ of accuracy), then areas were calculated by
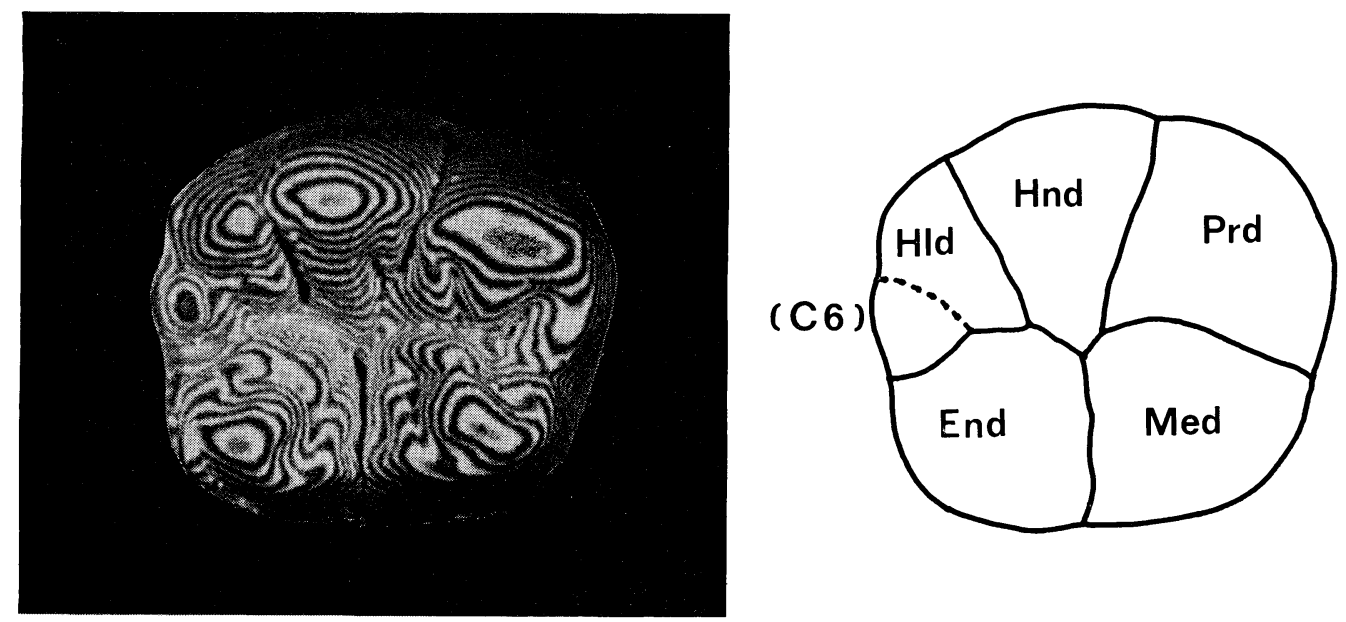

Fig. 1. A moiré photograph of the occlusal surface of the mandibular first molar (left) and the tracing of 5 or 6 cusps (right). Prd, protoconid; Med, metaconid; Hnd, hypoconid; End, entoconid; Hld, hypoconulid; 6 , sixth cusp. 
a microcomputer. Tracing was made three times on each cusp and the averages were obtained as a cusp area. Many of the first molars have Dryopithecus pattern (Y5), and some have the sixth cusp (C6) especially in Aboriginals. The seventh cusp was not found in the present materials.

\section{Results}

Morphological characteristics of the materials are shown in Table 1. Frequency of appearance of sixth cusp was remarkably high $(62.5 \%)$ in Aboriginals, while it is low $(2.3 \%)$ in Dutch population. Frequencies of fissure patterns do not differ greatly among populations. In an old literature (HELLMAN, 1928), it is said that Aboriginals never have +5 or Y4 patterns in lower first molars. However, the contact of protoconid and entoconid is often observed by the precise moiré photographs. The incidence of Y5 pattern in Japanese is almost the same with previous studies (SUZUKI and SAKAI, 1956; NAKANURA, 1957), and that in Dutch population is a little greater than the report already published (JøRGENSEN, 1955). Because the investigation of groove patterns is apt to be subjective depending on observers, the coincidence of frequencies of a population studied by different observers may be difficult.

Absolute (measured) values of the cusp areas are shown in Table 2. There are some significant differences in the total area of 5 cusps among the three populations. These differences are significant except for that between Japanese female and Dutch. Aboriginal male has the greatest total area, while the Dutch have the smallest one. Japanese male and female have intermediate values.

As for protoconid, metaconid, hypoconid and entoconid, the areas are greatest in Aboriginals and smallest in Dutch. However, the same population order is not seen in the case of hypoconulid. In Aboriginals and Japanese, the fact that not a few individuals have $\mathrm{C} 6$ makes the mean value of the area of hypoconulid smaller, because C6 often occupies the distal part of it. When C6 is not so large, it seems to be an accessory

Table 1. Cusp number and groove patterns of the lower first molars used in the present study.

\begin{tabular}{|c|c|c|c|c|c|}
\hline & \multicolumn{2}{|c|}{ Japanese } & \multirow{2}{*}{$\frac{\text { Dutch }}{\text { sex combined }}$} & \multicolumn{2}{|c|}{ Australian aborigines } \\
\hline & male & female & & male & female \\
\hline $\mathrm{N}$ & 39 & 38 & 43 & 24 & 16 \\
\hline Y5 & 17 & 25 & 33 & 8 & 6 \\
\hline 5 cusps +5 & 9 & 7 & 4 & 1 & \\
\hline X5 & 2 & & & & \\
\hline Total of 5 cusps & 28 & 32 & 42 & 9 & 6 \\
\hline Ratio of 5 cusps & $(71.8 \%)$ & $(84.2 \%)$ & $(97.7 \%)$ & $(37.5 \%)$ & $(37.5 \%)$ \\
\hline $\mathrm{Y} 6$ & 7 & 5 & 1 & 12 & 7 \\
\hline 6 cusps +6 & 4 & 1 & & 2 & 2 \\
\hline $\mathrm{X} 6$ & & & & 1 & 1 \\
\hline Total of 6 cusps & 11 & 6 & 1 & 15 & 10 \\
\hline Ratio of 6 cusps & $(28.2 \%)$ & $(15.8 \%)$ & $(2.3 \%)$ & $(62.5 \%)$ & $(62.5 \%)$ \\
\hline
\end{tabular}


Table 2. Cuspal areas of the lower first molar $\left(\mathrm{mm}^{2}\right)$.

\begin{tabular}{|c|c|c|c|c|c|c|c|c|c|c|}
\hline & \multicolumn{4}{|c|}{ Japanese } & \multirow{2}{*}{\multicolumn{2}{|c|}{$\begin{array}{c}\text { Dutch } \\
\text { sex combined }\end{array}$}} & \multicolumn{4}{|c|}{ Australian aborigines } \\
\hline & \multicolumn{2}{|c|}{ male } & \multicolumn{2}{|c|}{ female } & & & \multicolumn{2}{|c|}{ male } & \multicolumn{2}{|c|}{ female } \\
\hline $\mathrm{N}$ & 3 & & & & & & & & & 6 \\
\hline 1. Protoconid & $\begin{array}{l}\text { mean } \\
26.8\end{array}$ & $\begin{array}{l}\text { S.D. } \\
\text { 3. } 08\end{array}$ & $\begin{array}{c}\text { mean } \\
24.9\end{array}$ & $\begin{array}{l}\text { S.D. } \\
2.56\end{array}$ & $\begin{array}{c}\text { mean } \\
24.4\end{array}$ & $\begin{array}{l}\text { S.D. } \\
2.18\end{array}$ & $\begin{array}{c}\text { mean } \\
28.3\end{array}$ & $\begin{array}{l}\text { S.D. } \\
2.85\end{array}$ & $\begin{array}{l}\text { mean } \\
27.4\end{array}$ & $\begin{array}{l}\text { S. D. } \\
3.09\end{array}$ \\
\hline 2. Metaconid & 21.7 & 2.04 & 20.9 & 2.93 & 20.6 & 1.87 & 23.1 & 1.45 & 22.6 & 2.31 \\
\hline 3. Hypoconid & 21.5 & 3.16 & 19.2 & 2.64 & 19.2 & 2.48 & 24.1 & 3.30 & 22.7 & 2.71 \\
\hline 4. Entoconid & 22.6 & 3.78 & 21.2 & 2.89 & 19.6 & 2.17 & 23.3 & 3.09 & 23.3 & 2.17 \\
\hline 5. Hypoconulid & 12.2 & 3.18 & 11.9 & 2.88 & 12.3 & 2.31 & 12.8 & 4.09 & 12.5 & 3.05 \\
\hline $\begin{array}{l}\text { 6. 6th cusp } \\
(\mathrm{n})\end{array}$ & $\begin{array}{r}4.7 \\
(11)\end{array}$ & 1.75 & $\begin{array}{l}4.1 \\
(6)\end{array}$ & 1.43 & $\begin{array}{l}2.1 \\
(1)\end{array}$ & - & $\begin{array}{r}5.0 \\
(15)\end{array}$ & 2.97 & $\begin{array}{r}4.7 \\
(10)\end{array}$ & 2.10 \\
\hline $\begin{array}{l}\text { 7. Hypoconulid } \\
\text { +6th cusp }\end{array}$ & 13.5 & 4.06 & 12.5 & 2.45 & 12.3 & 2.22 & 15.9 & 4.04 & 15.4 & 3.54 \\
\hline 8. Total area & 106.1 & 11.58 & 98.8 & 7.72 & 96.1 & 6.12 & 114.7 & 9.86 & 111.4 & 10.72 \\
\hline
\end{tabular}

conule of hypoconulid. This cusp originally developed from the distal marginal ridge. Sometimes the cases in which it developed larger than hypoconulid were found. Even in such a case, a certain separation between C6 and entoconid can be seen. The functional meaning of the $\mathrm{C} 6$ is thought to fill the distal open space between hypoconulid and entoconid to occlude against hypocone of the maxillary molar together with hypoconulid. Concerning these circumstances, it can be said that hypoconulid and $\mathrm{C} 6$ make a single unit (a large hypoconulid so to speak). Total values of hypoconulid and C6 were consequently shown in Table 2 .

Fig. 2 shows the result of significance test of population difference of the cusp area. Shadowed and dotted areas denote cusps having significant differences at $5 \%$ and $1 \%$ levels, respectively. Asterisks also indicate the population differences of the total area at $1 \%$ level of significance. For example, between Aboriginal male and Japanese male, a diagram of molar occlusal surface at the third row and the second column in Fig. 2 shows that the significant differences were seen in total area, hypoconid and metaconid at $1 \%$ level and in hypoconulid at $5 \%$ level. Sex differences in Japanese were found in total area and two cusps (Fig. 2). Those in Aboriginals were not found. Differences between Dutch and Aboriginals (male and female) were seen in all cusps and total areas. The cusps which have significant differences between Japanese male and Aboriginal male do not coincide with those between Japanese female and Aboriginal female.

Cusp areas reflect the general size of the molar, while their percent sizes (KATo, 1980) to total area represent the proportion of cusps or shape of the occlusal aspects. Table 3 shows the percent cusp areas of the lower molar in three populations. Population differences of these values decrease in contrast to the cases of absolute values. Tendencies seen in this table show that hypoconulid (including C6) in Aboriginals, entoconid in Japanese and metaconid in Dutch are larger, and that hypoconid in Japanese female and protoconid in Aboriginals are smaller. However, t-test reveals signi- 

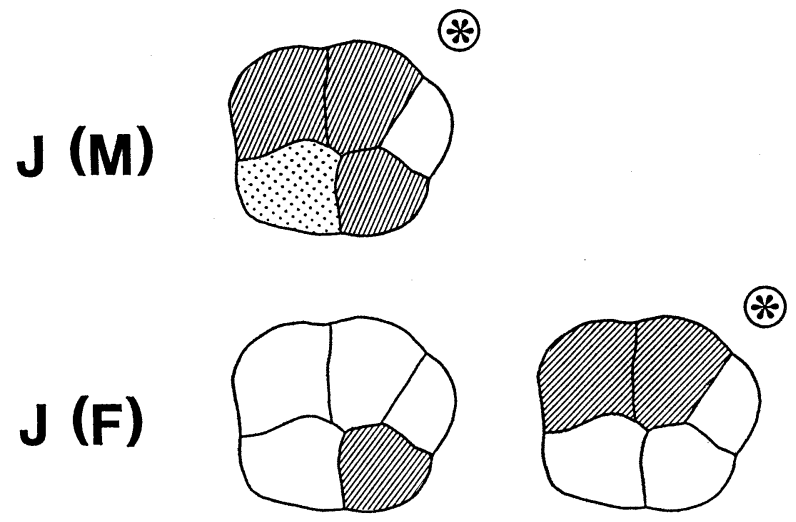

*)
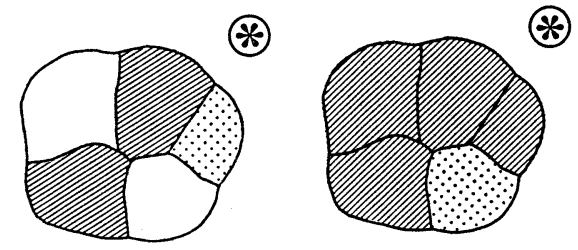

A (M)
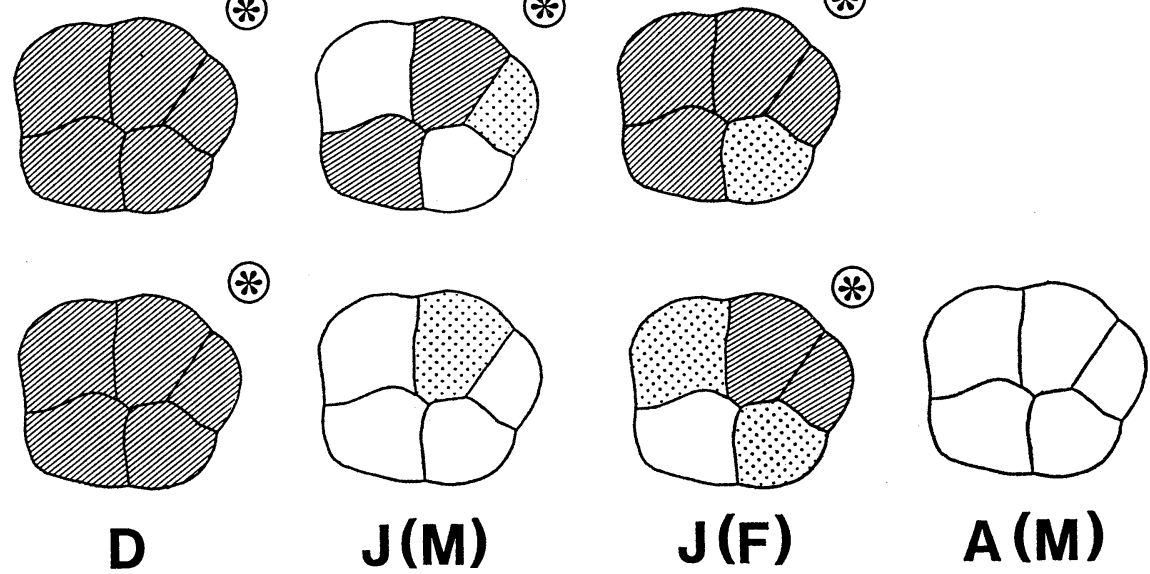

Fig. 2. Inter-populational differences of absolute (measured) cuspal areas. J, Japanese; A, Australian Aboriginals; D, Dutch; M, males; F, females. Significance levels of differences in cuspal areas were expressed as shadowed $(1 \%)$ and dotted $(5 \%)$ patterns. Asterisks in circle denote $1 \%$ level of differences in the total of cusp areas. WeLCH's approximate significance test for the difference between two means was done with different variation.

Table 3. Percent cuspal areas of the lower first molar (\%).

\begin{tabular}{|c|c|c|c|c|c|c|c|c|c|c|c|}
\hline & \multicolumn{4}{|c|}{ Japanese } & \multirow{2}{*}{\multicolumn{2}{|c|}{ 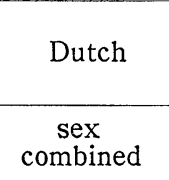 }} & \multicolumn{4}{|c|}{ Australian aborigines } & \multirow{2}{*}{$\begin{array}{c}\begin{array}{c}\text { Plio-Pleis- } \\
\text { tocene } \\
\text { hominids }\end{array} \\
\begin{array}{c}\text { WoOD } \\
1983)\end{array}\end{array}$} \\
\hline & \multicolumn{2}{|c|}{ male } & \multicolumn{2}{|c|}{ female } & & & \multicolumn{2}{|c|}{ male } & \multicolumn{2}{|c|}{ female } & \\
\hline & mean & S.D. & mean & S. D. & mean & S.D. & mean & S.D. & mean & S.D. & mean (range) \\
\hline 1. Protoconid & 25.3 & 2.17 & 25.2 & 1.82 & 25.3 & 1.64 & 24.7 & 2.10 & 24.6 & 1.47 & $20.9 \sim 24.4$ \\
\hline 2. Metaconid & 20.5 & 1.73 & 21.2 & 2.68 & 21.4 & 1.41 & 20.3 & 1.58 & 20.4 & 2.08 & $22.0 \sim 24.3$ \\
\hline 3. Hypoconid & 20.3 & 1.99 & 19.5 & 2.26 & 20.1 & 2.17 & 20.9 & 1.90 & 20.4 & 1.19 & $19.7 \sim 22.7$ \\
\hline 4. Entoconid & 21.3 & 2.56 & 21.5 & 2.30 & 20.3 & 1.67 & 20.3 & 2.04 & 20.9 & 1.28 & $15.3 \sim 19.3$ \\
\hline $\begin{array}{l}\text { 5. Hypoconulid +6th } \\
\text { cusp }\end{array}$ & 12.5 & 2.95 & 12.6 & 2.12 & 12.9 & 2.35 & 13.8 & 2.84 & 13.7 & 2.29 & $14.5 \sim 18.8$ \\
\hline
\end{tabular}



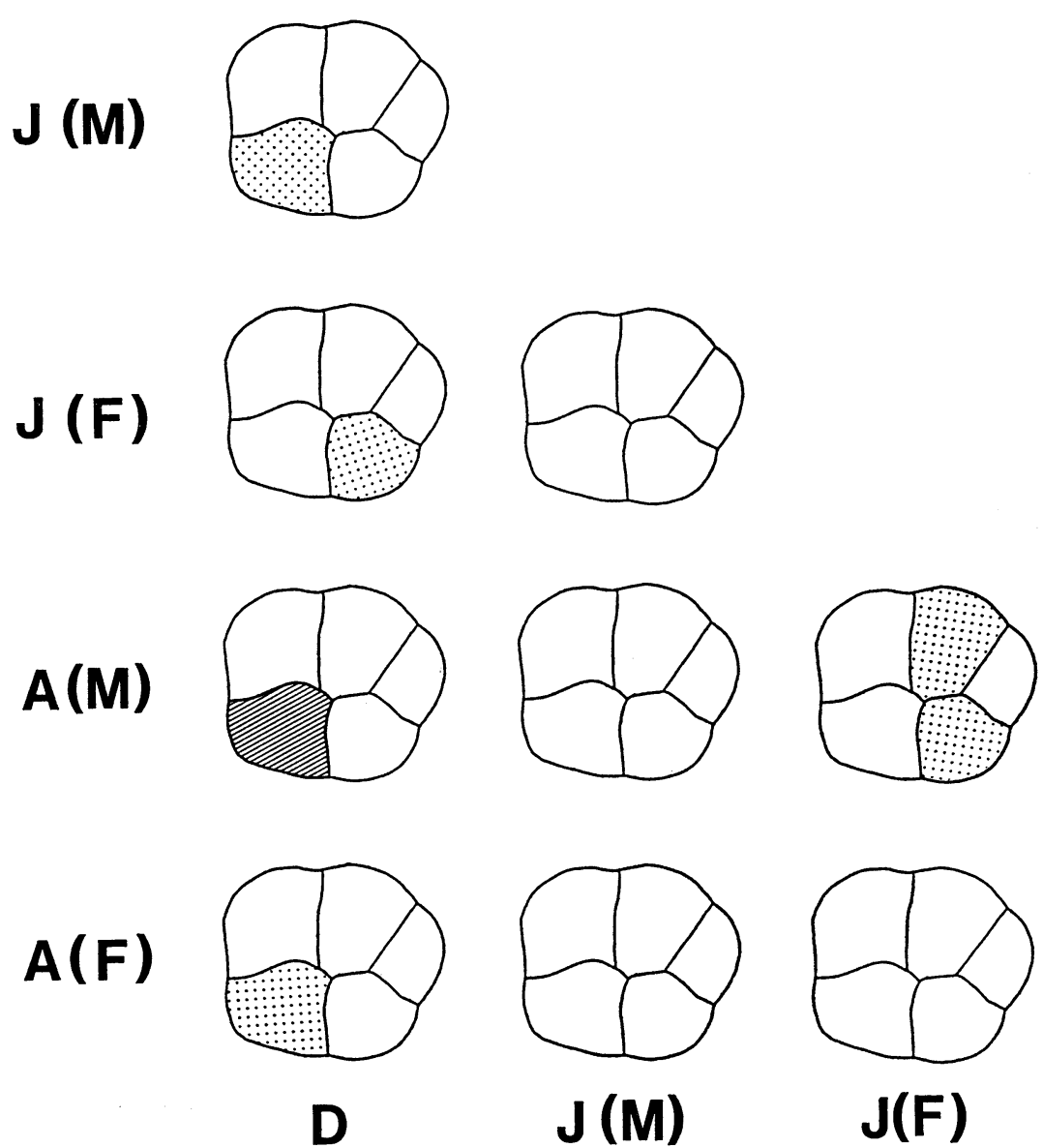

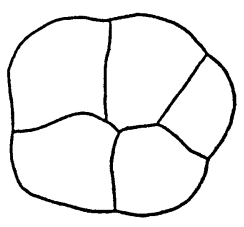

$\mathrm{J}(\mathrm{M})$

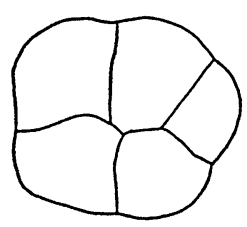

$J(F)$

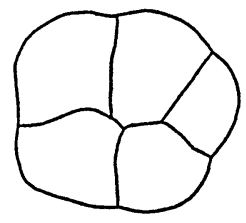

$A(M)$

Fig. 3. Inter-populational differences of persentage cusp areas. As for abbreviations and significance levels, see figure 2 .

ficant differences seen only in 6 out of 50 comparisons. Even hypoconulid $(+\mathrm{C} 6)$ does not show racial differences because of its high variability (Fig. 3).

Items having significant racial differences at $5 \%$ level are as follows.

Metaconid: Dutch $>$ Japanese male Dutch $>$ Aboriginal male (significant at $1 \%$ level) Dutch $>$ Aboriginal female

Entoconid: Japanese female $>$ Dutch Japanese female $>$ Aboriginal male Hypoconid : Aboriginal male $>$ Japanese female
The percent cusp areas in fossil PlioPleistocene hominids (Australopithecus) have already been investigated by WooD et al . (1983), the data of which are summarized in Table 3. These values vary greatly in fossils. However, they represent a tendency that both hypoconulid and metaconid are larger and both entoconid and protoconid are smaller than modern hominids in the present study. It is noted that the numerical arrangement of the values of cusp areas in Aboriginals seems to be closest to that of fossil materials. Although no 
statistical significance of this similarity is demonstrated, it might support the view that the molar of Aboriginals has comparatively primitive characteristics.

Table 4 shows correlation matrices of absolute and percentage cusp areas in 5 groups. In the matrix of absolute cusp areas (lower triangular half of each matrix) of Japanese male, correlation coefficient between hypoconid and protoconid is significant and highest. All the other correlation coefficients are also significant. In Japanese female, metaconid and hypoconid have low correlations with others except for with protoconid, which highly correlates with others. In the matrix of absolute values of

Table 4. Correlation matrices of cusp areas. Correlations of absolute values are in left lower half and those of relative areas are in right upper half. *Correlations between absolute value of total area and relative values of cusp areas.

\begin{tabular}{|c|c|c|c|c|c|c|c|}
\hline & & (1) & $(2)$ & $(3)$ & $(4)$ & $(5)$ & $(6)^{*}$ \\
\hline \multirow[t]{6}{*}{ Japanese male } & 1. Prd. & & -.125 & -.036 & -.206 & -.461 & -.308 \\
\hline & 2. Med. & .292 & & -.088 & -.166 & -.292 & -.502 \\
\hline & 3. Hnd. & .526 & .441 & & -.387 & -.259 & .030 \\
\hline & 4. End. & .349 & .370 & .326 & & -.357 & .055 \\
\hline & 5. Hld. & .306 & .472 & .424 & .287 & & .458 \\
\hline & 6. Total & .691 & .670 & .754 & .682 & .734 & \\
\hline \multirow[t]{6}{*}{ Japanese female } & 1. Prd. & & -.537 & .013 & -.116 & -.064 & -.067 \\
\hline & 2. Med. & -.048 & & .349 & -.199 & -.216 & -.121 \\
\hline & 3. Hnd. & .373 & .032 & & -.345 & -.257 & -.037 \\
\hline & 4. End. & .383 & .131 & .076 & & -.365 & .046 \\
\hline & 5. Hld. & .363 & .081 & .127 & .086 & & .210 \\
\hline & 6. Total & .710 & .434 & .529 & .613 & .553 & \\
\hline \multirow[t]{6}{*}{ Dutch } & 1. Prd. & & -.305 & -.105 & -.150 & -.304 & .002 \\
\hline & 2. Med. & .350 & & -.402 & .136 & -.102 & .032 \\
\hline & 3. Hnd. & .367 & .161 & & -.226 & -.428 & .070 \\
\hline & 4. End. & .417 & .550 & .245 & & -.477 & .151 \\
\hline & 5. HId. & -.109 & .040 & -.259 & -.228 & & -.192 \\
\hline & 6. Total & .718 & .702 & .570 & .686 & .155 & \\
\hline \multirow[t]{6}{*}{ Aboriginal male } & 1. Prd. & & .217 & -.248 & -.149 & -.588 & -.300 \\
\hline & 2. Med. & .300 & & -.429 & .034 & -.458 & -.715 \\
\hline & 3. Hnd. & .474 & .284 & & -.316 & -.014 & .347 \\
\hline & 4. End. & .332 & .383 & .394 & & -.416 & .037 \\
\hline & 5. Hld. & .060 & .059 & .485 & .162 & & .362 \\
\hline & 6. Total & .620 & .473 & .833 & .663 & .647 & \\
\hline \multirow[t]{6}{*}{ Aboriginal female } & 1. Prd. & & -.370 & .097 & -.100 & -.299 & .005 \\
\hline & 2. Med. & .252 & & -.236 & -.160 & -.459 & -.447 \\
\hline & 3. Hnd. & .777 & .381 & & .010 & -.369 & .175 \\
\hline & 4. End. & .642 & .199 & .734 & & -.355 & -.374 \\
\hline & 5. Hld. & .583 & .198 & .559 & .548 & & .525 \\
\hline & 6. Total & .860 & .490 & .890 & .795 & .792 & \\
\hline
\end{tabular}


Aboriginal males, it is noted that hypoconulid does not show high correlations with others except for with hypoconid. In Aboriginal females, correlation coefficients are higher except for those with metaconid. In Dutch population, the coefficients on hypoconulid are either close to zero or negative. This fact shows that the size of hypoconulid varies independently with other cusp areas.

In the correlation matrices of percent values (upper right triangular half of each matrix in Table 4), it is noted that almost all the correlation coefficients are of negative values. These values represent the compensatory relation between percent cusp areas when the total area is constant. In the correlation coefficients between percent cusp areas and the total area, some large positive or negative values are seen in Japanese male and Aboriginals. When the correlation is nearly zero or statistically non-significant, the cusp area is considered to be isometric to the total area. Thus, these positive and negative values

Table 5. Correlation and regression slopes of $\log$ cusp area $\ln (\mathrm{c})$ and $\log$ total area $\ln (\mathrm{t})$.

\begin{tabular}{llcccc}
\hline \multirow{2}{*}{ Japanese male } & & $\begin{array}{c}\text { correlation between } \\
\text { ln (c) } \text { and } \ln (\mathrm{t})\end{array}$ & $\begin{array}{c}\text { regression } \\
\text { slope }\end{array}$ & $\begin{array}{c}\text { standard error } \\
\text { of the slope }\end{array}$ & $\begin{array}{c}\text { allometry } \\
(\mathrm{P}<.05)\end{array}$ \\
& Prd. & 0.701 & 0.742 & 0.085 & - \\
& Med. & 0.666 & 0.604 & 0.072 & - \\
& Hnd. & 0.746 & 1.030 & 0.110 & 0 \\
& End. & 0.691 & 1.047 & 0.121 & 0 \\
& Hld. & 0.704 & 2.035 & 0.231 & + \\
& Prd. & 0.710 & 0.926 & 0.106 & 0 \\
& Med. & 0.423 & 0.789 & 0.116 & 0 \\
& Hnd. & 0.538 & 0.929 & 0.127 & 0 \\
& End. & 0.614 & 1.040 & 0.133 & 0 \\
& Hld. & 0.589 & 1.473 & 0.193 & + \\
& Prd. & 0.709 & 1.014 & 0.109 & 0 \\
& Med. & 0.717 & 1.058 & 0.112 & 0 \\
& Hnd. & 0.516 & 1.127 & 0.147 & 0 \\
& End. & 0.683 & 1.196 & 0.133 & 0 \\
& Hld. & $0.128($ n.s. & 0.388 & 0.059 & 0 \\
& Prd. & 0.604 & 0.696 & 0.113 & - \\
& Med. & 0.462 & 0.343 & 0.062 & - \\
& Hnd. & 0.792 & 1.461 & 0.182 & + \\
& End. & 0.673 & 1.048 & 0.158 & 0 \\
& Hld. & 0.578 & 1.725 & 0.287 & + \\
Aboriginal female & Prd. & 0.859 & 1.003 & 0.128 & 0 \\
& Med. & 0.504 & 0.538 & 0.116 & - \\
& Hnd. & 0.882 & 1.108 & 0.130 & 0 \\
& End. & 0.792 & 0.765 & 0.116 & + \\
& Hld. & 0.805 & 1.858 & 0.275 & + \\
\hline
\end{tabular}

n. s., correlation is not significant, $-:$ negative allometry, $+:$ positive allometry, $0:$ isometry. 
demonstrate deviations from isometry to allometry. Japanese female and Dutch populations show no such allometric trend.

To get allometric coefficients, the regression line of the $\log$ cusp area on the log total area was obtained (Table 5). The slope of this line is the estimated allometric coefficient. When it is nearly 1.0, cusp area shows isometry. If it is larger or smaller than 1.0 , it is positive or negative allometry, respectively (REEVE and HUXLEY, 1945, TAKAI and Terada, 1973, Hayami, 1969). The significance of isometry can be tested statistically by the regression slope (b) and standard error of the slope $(\mathrm{SE}(\mathrm{b}))$. As the variate $(b-1.0) / S E(b)$ represents approximately normal distribution $(\overline{\mathrm{x}}=0, \mathrm{~S} . \mathrm{D} .=1)$, the probability of isometry was calculated. Allometry was supposed in this paper when the variate was larger or smaller than $95 \%$ of confidence limits. Cusps showing positive and negative allometry were presented in Table 5 .

\section{Discussion}

The significances of the cusp area in human molars are considered as follows.

1) When the occlusal surface as a whole or cusp areas are large, efficiency of mastication is thought to be high. 2) When a certain cusp is large relative to other cusps, a function converges on it. Contrarily, small cusps cannot bear on heavy function. 3) Two-dimensional arrangements of cusps in varied sizes influence the positions of cuspal tips. Tips are the most effective parts for shearing foods in mastication and occlusion. 4) Two-dimensional arrangements of cusps also have close relation to the pattern of grooves. They sometimes give paths for cusps of corresponding tooth during mandibular movement. The studies of the molar cusp area to clarify these significances are, for example, quantitative representation of the reduced characters appearing on certain cusps (OzAKI, 1967; HANIHARA, 1970 ; NEGISHI, 1972; NAGASHIMA, 1975; KATO, 1980), how groove patterns of Y5, Y4 or +4 relate with the cusp areas (ERDBRINK, 1965; KAMIJO, 1974) and description in detail of the molars of fossil hominids (CORRUCCINI and MCHENRY, 1980; MCHENRy and CoRruccini, 1980a, b) or recent anthropoids (HILls et al. 1983).

A character of the lower molar which has been most actively investigated by many authors was the groove pattern represented by Dryopithecus pattern (GREGORY, 1916). The frequency of the Dryopithecus pattern in different racial populations was widely investigated, and it was revealed that the pattern appeared most frequently in the first molar, then reduced to the third molar, and that the frequently was highest in Negroid, intermediate in Mongoloid, and lowest in Caucasoid. It is generally accepted that tooth form reduction progresses more in Caucasoid than in Negroid.

Our observation on the frequency of Dryopithecus pattern in the first molar of Aboriginals was a little different from the results of previous studies in which the frequency was $100 \%$. Our result showed that it was 81 or $83 \%$. Though the number of the teeth was not sufficient (male: 24, female: 16), two or three of them were found to have different groove patterns. Classification of the groove pattern has depended on observer's eyes. Our method would be more objective because the moire photograph of the molar surface was enlarged, then the groove was carefully traced in detail with the aid of contour lines. HELLMAN (1922) reported that the 
frequency of Dryopithecus pattern in the lower first molar in Chinese was also $100 \%$. According to detailed studies, it was not $100 \%$, but 62 to $67 \%$ in Japanese whose physical character is very close to Chinese, both belonging to Mongoloid. It can be said that the HELlmaN's data are probably biased by both the insufficient number of samples and subjective method of classification.

The incidence of Dryopithecus pattern in the lower first molar in the present study does not show clear racial difference, while those of $\mathrm{C} 6$ were different in three populations with concordance of previous studies (NAKAMURA, 1957 ; SUZUKI and SAKAI, 1973). In the measurement of the cusp areas, a problem arises in C6. WooD et al. (1983) divided the area of $\mathrm{C} 6$ into two halves which were added to hypoconulid and entoconid, respectively. This impartial method was thought to be proper to compare the lower molar having $\mathrm{C} 6$ with normal molars. It would be based on the idea that no judgement was possible to which cusp $C 6$ belongs. C6 is derived from additional infolding of the enamel organ epithelium (REMANE, 1960 ; WooD et al. 1983), appears between hypoconulid and entoconid as if it filled the distal space, and situates more closely to hypoconulid than to entoconid. It is functionally more or less the same with hypoconulid, because it occludes with hypocone of the corresponding maxillary tooth.

Consequently, C6 area was included in hypoconulid in the analysis of this study. So the value of hypoconulid became large in the case of a molar having C6. Nevertheless, no significant racial difference of the area of hypoconulid (C6 included) was found in relative values. It means that though the frequency of $\mathrm{C} 6$ in Aboriginals is high, the total area of $\mathrm{C} 6$ and hypoconulid is not so large as to change the proportion of the distal part of the lower first molar at the population level.

Previous studies (CORRUCCINI and MCHENRy, 1980 ; MCHENRy and CoRruccini, 1980 , a, b) on the relative cusp size of human mandibular molars suggest that robust Australopithecus has relatively small protoconid and metaconid, and a relatively large hypoconulid. HiLls (1983) made more extensive research on relative cusp size in Homo sapiens, Gorilla and Pongo. Then he concluded that intraspecific allometry was found in entoconid and hypoconulid in Homo and interspecific allometry was found in metaconid and entoconid. His human materials were originated from ERDBRINK's (1965) collection which includes Frisians and deutero-Malayans. In these materials, correlation coefficients between relative cusp area and total area are not so high, and allometric trend was seen only in distal cusps. Dutch population in the present study shows no trend of allometry, and Japanese females show allometry only in hypoconulid. However, Japanese male and Aboriginals have strong allometry not only in hypoconulid with positive one but also in mesial cusps with negative one. It may be due to the relatively large size of molars or the range of variability in these groups.

The purpose of this study is the comparison of molar occlusal form in three representative human populations. It had been expected before hand that great differences were seen in absolute cuspal areas. However, there were no distinctive differences in relative cusp areas. It suggests that the proportion of cusp areas is not different among existent populations. Aust- 
ralopithecus had large occlusal surface area of mandibular molars up to $187 \mathrm{~mm}^{2}$. It is twice of recent Homo. This big difference must influence the proportion of relative cusp areas which in fact are apparently different from modern man. Although it might be difficult to test statistically, it is indicated that those of Australian Aboriginals are nearest to those of Australopithecus. Australian Aboriginals are, of course, not originated directly from these fossil hominids. It is suggested that same functional needs operate on relatively large molar in these populations being far apart in time from each other.

The present study revealed that there was negative allometry in mesial cusps (protoconid and metaconid in Japanese male and Aboriginals) and positive allometry in hypoconulid (both sexes in Japanese and Aboriginals). These two contrastive allometries in mesial and distal parts were not found in HILL's (1983) results in which entoconid and hypoconulid in M1 show negative and positive allometry, respectively, and metaconid and entoconid in M2 show also negative and positive allometry, respectively. It seems that there is no uniformity of allometry in these two kinds of molars. The reason for it is unclear. From these results he proposed negative conclusion to both hypotheses that the reduction of the trigonid in the 'robust' Australopithecus is an allometric phenomenon, and that there is a pervading trend for any increase in the relative size of the distal part of the crown in larger-toothed individuals. However, if the statistical allometric trend in the present study is reasonable analogues for allometric relationship within, or between, the fossil hominid taxa, the two hypotheses can be supported by our results where, in Japanese male and Aboriginals, the negative allometry is distinctive in mesial cusps (trigonid) and the positive allometry in hypoconulid.

There is another controversy about size relationship between hypoconid and entoconid. In 'robust' Australopithecus, there are two opponent interpretations that entoconid is larger than hypoconid (Wood et al., 1983) and that the reverse is true (McHenRy and Corruccini, 1980). Hills et al. (1983) suggested about this controversy that different methods for recording cusp size may explain the discrepancies in these results. The fact that allometries were not found in hypoconid and entoconid except for Aboriginals in the present study suggests disintegration of morphological unity of cusps forming talonid. The above mentioned controversy may be due to this phenomenon.

In order to confirm our results either to be general trends in human evolution or to be particular phenomena in the present materials, further studies on the second mandibular molar and maxillary molars are needed.

\section{Acknowledgement}

We are grateful to Prof. T. BRown, University of Adelaide, South Australia, and to the late Prof. J. VAN LimbORGH, University of Amsterdam, the Netherlands, for giving us opportunities to make replicas and measure dental materials. Thanks are also due to Dr. H. SAKURA, National Science Museum, Tokyo, and to Dr. S. TAKAI, Saga Medical School, for critical reading of the manuscript, and to Dr. SATAKE, Nihon University School of Dentistry at Matsudo, for suggestions on the references. 


\section{References}

Corruccini, R.S. and H.M. MCHenry, 1980: Cladometric analysis of Pliocene hominids. J. Hum. Evol., 9 : 209-221.

ERDBRINK, D.P., 1965: A quantification of the Dryopithecus and other lower molar patterns in man and some of the apes. Z. Morph. Anthrop., $57:$ 70-108.

GREGORY, W.K., 1916: Study on the evolution of the primates. Part II. Phylogeny of recent and extinct anthropoids, with special reference to the origin of man. Bull. Am. Mus. Nat., $35,235-355$.

Hanihara, K., M. Tamada and T. Tanaka, 1970: Quantitative analysis of the hypocone in the human upper molars. J. Anthrop. Soc. Nippon., $78: 200-207$.

HAYAMI, I., 1969: Mensuration of fossils and statistics. Bull. Fac. Sci., Kyushu Univ., 10: 67-90. (in Japanese with English abstract)

HELlman, M., 1928: Racial characters in human dentition. Proc. Am. Phylos. Soc., 67: 157-174.

Hills, M., S.H. Graham and B.A. Wood, 1983 : The allometry of relative cusp size in hominoid mandibular molars. Am. J. Phys. Anthrop., $62: 311-316$.

JøRGENSEN, K.D., 1955: The Dryopithecus pattern in recent Danes and Dutchmen. J. Dent. Res., 34 : 195-208.

Kamijo, Y., J. Nomura and K. Ichikawa, 1974 : Studies on sizes of cusps in Dryopithecus pattern of lower first molar. Bull. Tokyo dent. Coll., 74: 316-324. (in Japanese with English summary)

Kanazawa, E., M. Sekikawa and T. Ozaki, 1983: Three-dimensional measurements of the occlusal surface of upper first molars in a modern Japanese population. Acta anat., 116: 90-96.

Kanazawa, E., M. Sekikawa and T. Ozaki, 1984: Three-dimensional measurements of the occlusal surfaces of upper molars in a Dutch population. J. Dent. Res., 63 : 1298-1301.

KAто, K., 1980: Cusp area index of the Japanese molars. Nihon Univ. J. oral Sci., 6: 304-309. (in Japanese with English abstract)

McHenry, H.M. and R.S. Corruccini, 1980a: Late Tertiary hominoids and human origins. Nature, $285: 397-398$.

MCHenry, H.M. and R.S. Corruccini, 1980b:
On the status of Australopithecus afarensis. Science, 207, 1103-1104.

NAGAShima, S., 1975: The measurement of relative sizes of the cusp area in human molars. Part 2. The Australian Aboriginal teeth. Nihon Univ. J. oral Sci., 1:33-38. (in Japanese with English abstract)

NAKAMURA, M., 1957: Occlusal surface pattern of the lower molars in recent Japanese. Acta anat. Nippon., 32:510-528. (in Japanese with English summary)

NEGISHI, M., 1972: The measurement of relative sizes of the cusp area in the human molars. Part 1. The Japanese adult teeth. Nihon Univ. dent. J., 46:515-519. (in Japanese)

Ozaki, T., Kasuya, K., Negishi, M., Ito, H., Kubota, K., Tsuruoka, Y. and Wada, N., 1967: Morphological study of the occlusal surface of the maxillary molars in Japanese. The relative cuspal areas. Nihon Univ. dent. J., $41: 240$. (in Japanese)

Ozaki, T. and E. KanAzawa, 1984: An application of the moire method to three-dimensional measurements of the occlusal aspects of molars. Acta Morphol. Neerl.-Scand., 22: 85-91.

Ozaki, T., E. Kanazawa, M. Sekikawa and S. SAKURAI, 1984: Three-dimensional measurement of occlusal surface of lower first molars in Dutch population. Jpn. J. Oral Biol., 26: 241-248.

Ozaki, T., E. Kanazawa, M. Sekikawa and J. AKAI, 1985: Three-dimensional measurement of occlusal surface of upper first molars in Australian Aborigines. Aus. Dent. J. (in print) Reeve, E.C.R. and J.S. Huxley, 1945: Some problems in the study of allometric growth. In Essays on growth and form presented to D'Arcy Thompson. LE GROS ClaRK, W.E. and Medawar, P.B. (ed.). Oxford University Press, London, 121-156.

Remane, A., 1960: Zahne und Gebiss, Primatologia, III-2. S. Karger, New York, 637-846.

Sekikawa, M., J. Akai, A. Nambu, E. KanaZAWA and T. OzAKI, 1983: Three-dimensional measurements of the occlusal surface of lower first molars in a modern Japanese population. Jpn. J. Oral Biol., 25:737-744. (in Japanese with English abstract)

Suzuki, M. and T. SakaI, 1956: On the Dryopithecus pattern in recent Japanese. J. Anthrop. Soc. Nippon, 64: 135-139. (in Japanese with 
English summary)

Suzuki, M. and T. SAKaI, 1973: The Japanese Dentition. Morphological study of dental characteristics of the permanent teeth in recent Japanese. Mimeographed.

TAKAI, S. and H. TERADA, 1973: Radiogram- metric study on the allometry of human digits. J. Anthrop. Soc. Nippon, 81 : 145-152.

Wood, B.A., S.A. AbBotT and S.H. Graham, 1983: Analysis of the dental morphology of Plio-Pleistocene hominids. II. J. Anat., 137 : 287-314.

\title{
抄録
}

下顎第一大臼歯咬頭域面積のアロメトリーに関する人類学的研究

\author{
金沢英作・関川三男・赤井淳二・尾㠃 公 \\ 日本大学松戸歯学部第一解剖学教室
}

大臼歯の咬頭域面積の計測は近遠心径や煩舌 径と並んで重要な形質である。この面積の和, すなわち咬合面積の大小は咀嚼効率の指標とな る。個々の咬頭域面積は咬頭の相対的配置に関 係し, その変化は溝の形態や咬頭頂の位置, ひ いては咬合の機能にも影響を及ぼすと思われる。 我々はこの咬頭域面積の人種による差と咬頭相 互間の相対的大小関係を知る目的でこの調査を 行った。材料は咬耗の少ない下顎第一大曰歯で, 日本人（伊東市小学生）男子39例, 女子38例, オランダ白人・性別不明 43 例, オーストラリア 原住民（以下，豪原人) - 男子 24 例，女子16例 である。これらの歯は近心の2咬頭 (Protoconid と Metaconid) と遠心舌側咬頭 (Entoconid)の 3 咬頭頂を水平面とし，それに対し垂直な方向 からモアレ等高縞撮影装置 (K.K. 樫村製, Nikon F-3， 105 mm レンズ使用）により撮影 した。得られた等高縞写真上で, 各咬頭域をデ イジタイザーによりトレースし，マイクロコン ピュータを用いて面積の算出抒よび統計処理を 行った。

咬頭面積の合計値は歯の大きさを反映して豪 原人男子が最も大きく, $114.7 \mathrm{~mm}^{2}$, 最小は才 ランダ白人の $96.1 \mathrm{~mm}^{2}$ であった。各咬頭の大
きさも括括む称豪原人男子・女子・日本人男子 ・女子・オランダ白人の順であった（表 2 )。 各咬頭の面積をそれらの合計值で除した相対值 では各人種間に大きな差は見られなかった（表 3)。乙かし，豪原人では他人種に比べ近心の 2 咬頭が小さく, 遠心の hypoconulid が大きい。 このような傾向は化石人類 (Australopithecus ; WooD，1983）では顕著であり，また化石人類 では咬合面積が $185 \mathrm{~mm}^{2}$ にも達することを考 え合わせると豪原人の歯が現代人の中ではその 歯に質的にも量的にも近いことをらかがわせ 興味深い。咬頭面積の相対值々面積の合計値 との相関係数は咬頭の面積が全体に対し等成 長変異 (isometric variation) であるか不等 成長変異 (allometric variation) であるかを 示している。このアロメトリー傾向を成長指数 によって検定するために咬頭面積とその合計值 の対数をとり，それらの間の相関係数 (r) と回 帰係数 (b) 抢よび標準誤差 SE(b) を求めた。 回帰係数（成長指数）は全体の面積から各咬頭 面積を推定する回㷌直線の傾きである。これら を等成長を帰無仮説とする検定式を用いて検定 した結果，オランダ白人を除く各グループの hypoconulid とオランダ白人と日本人女子を除 
く各グループの protoconid 又は metaconid 現代人の変異現象からも説明できょう。Talonid にそれぞれ有意の正および負のアロメトリーの に関しては統一的なアロメトリーは見られず， あることがわかった。オランダ白人と日本人女 hypoconulid だけが顕著なアロメトリ一を示す。 子でアロメトリーの見られないことは歯のサイ 現生人種での下顎第一大臼歯のアロメトリーは ズが小さいことや第 6 咬頭の出現頻度が低いこ＼cjkstart歯の大きなグループで顕著であり，その中では とと関係があるかも知れない。これらの結果が 近心部が劣成長変異, 最遠心部が優成長変異で 進化にも適用できるとすれば大きな歯をもつ化 その間の hypoconid, entoconid では等成長変 石人種では trigonid が相対的に小さいという 異であると結論できる。 見解 (MCHENRY and CORRUCCINI, 1980)を

\section{金 沢 英 作 日本大学松戸歯学部第一解剖学教室} 厂271 千葉県松戸市栄町西 2 丁目870番 1

Eisaku Kanazawa Department of Anatomy, Nihon University School of Dentistry at Matsudo, 2-870-1 Sakae-cho Nishi, Matsudo-shi, Chiba 271, Japan 